\title{
フォトリソグラフィとアノード酸化を利用した $\mathrm{Al}$ 薄膜の表面加工
}

\author{
勝又 信行*，石田 正文*，斎藤＼cjkstart修* \\ *山梨県工業技術センター(† 400-0055 山梨県甲府市大津町 2094)
}

\begin{abstract}
Surface Patterning of Al Thin Film Using Photolithography and Anodization
\end{abstract}
Nobuyuki KATSUMATA*, Masafumi ISHIDA* and Osamu SAITO*

*Yamanashi Prefectural Industrial Technology Center(2094, Ohtsu-machi, Kofu-shi, Yamanashi 400-0055)

\begin{abstract}
This paper addresses a new method of surface patterning for thin aluminum films using photolithography, anodization, and chemical etching. Aluminum film with a thickness of about $150 \mathrm{~nm}$ was deposited on titanium-coated silicon or slide glass substrates. Subsequently, square masks were patterned on the aluminum film using photolithography. While aluminum film was anodized in 1 vol\% sulfuric acid, an anodic oxide film formed in the photoresist/aluminum film interface in addition to on open surface regions. In this process, the thickness of the anodic oxide film formed under the photoresist was affected by the bath voltage and the thickness of the titanium layer. Since the thickness of the anodic oxide at open surface regions and at masked regions differed, a patterned surface was developed. In order to examine the surface morphology, the anodic oxide film was removed by chemical etching in 21 vol\% phosphoric acid. As result, the anodic oxide film was removed, leaving an aluminum film of convex shape on the substrate.
\end{abstract}

Keywords : Photolithography, Anodization, Surface Patterning, Chemical Etching

\section{1. 緒 言}

表面への微細凹凹形状の加工は, 光学特性やトライボロジ などをはじめとするさまざまな機能を付与できる可能性があ ることから, 各種加工技術が研究され ${ }^{1) \sim 4)}$, その機能の検証 が行われている5),6)。

これらの微細加工1),3) では, 従来から研究されてきたフォ トリソグラフィとエッチング7) 9) を組み合わせた除去加工で はなく, 表面を局所的に隆起させることで微細な凹凸形状を 創成することが提案されている。表面が隆起する現象には, これらで提案されている以外にアルミニウムなどをアノード 酸化すると表面に酸化膜が生成し，このときに体積が膨張す ることが知られている。この現象を微細加工に利用できれば, 比較的低コストで大面積を一括処理できる加工技術として利 用できると考えられる。たとえば，フォトリソグラフィによ りマスクパターンを形成した表面をアノード酸化することで, マスク開口部表面に酸化膜を形成し，この酸化膜の形成にと もなう体積膨張によってマスク開口部表面を局所的に隆起さ せることで凹凹形状を形成する方法である。また，この隆起 した表面には,アノード酸化時の自己組織化によって規則的 な多孔質構造が得られる可能性もある ${ }^{10) ~ 12) 。 以 上 の こ と か ~}$ ら，フォトリソグラフィとアノード酸化を組み合わせること で, 表面へのマスク形状に対応した凹凸形状の付与と酸化膜 表面へのナノメータースケールの微細構造を同時に形成でき る可能性がある。しかし，このことについて系統的に調査し
た報告例は数少なく ${ }^{13)}$, このことを検証するためには, 局所 的な酸化膜の形成に関わる調査と酸化膜表面の微細構造につ いて調査する必要がある。特にフォトリソグラフィ後の酸化 膜形成過程において，フォトリソグラフィと電解エッチング

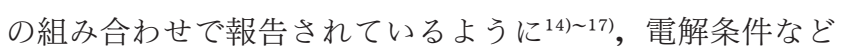
を制御することによってマスク下部で進行する反応が制御で きれば, 作製できる表面形状の自由度が増し, 新しい表面加 工技術と応用分野の可能性を見いだすことができると考えら れる。

そこで本研究では，この第一段階として局所的な酸化膜の 形成と隆起に関する基礎的な知見を得るために，スパッタリ ング法により成膜した $\mathrm{Al}$ 薄膜に対してフォトリソグラフィ とアノード酸化を組み合わせた表面処理を行い, 新しい表面 加工技術としての可能性について検討した。

\section{2. 実験方法}

\section{2. $1 \mathrm{Al}$ 薄膜の作製}

被加工物となる $\mathrm{Al}$ 薄膜の成膜には, カルーセル型マルチ ターゲット高周波マグネトロンスパッタリング装置(アネル バ製 L-350 S-C) を使用した。基板材料には, 約 $40 \times 60$ $\mathrm{mm}$ に割断した $\mathrm{Si}$ 基板と約 $76 \times 52 \mathrm{~mm}$ のスライドガラスを, ターゲット材には $99.99 \mathrm{wt} \% \mathrm{Al}$ と $99.99 \mathrm{wt} \% \mathrm{Ti}$ をそぞ れ用い, スパッタリングガスには,Arガス (99.999 mass\%) を用いた。また基板と $\mathrm{Al}$ 薄膜間に密着性向上を目的として, $\mathrm{Ti}$ 膜を約 $10 \mathrm{~nm}$ 成膜した。 $\mathrm{Al}$ 薄膜の膜厚は，成膜時間によ 
り制御し，目標膜厚を $150 \mathrm{~nm}$ とした。作製した $\mathrm{Al}$ 薄膜上 にフォトレジスト(東京応化製 OFPR-800)をスピンコータ で約 $1 \mu \mathrm{m}$ の厚さになるように塗布し, その後 $363 \mathrm{~K}$ に設定 したホットプレート上でプレベーキングを $50 \mathrm{~s}$ 間行った後, 露光, 現像, 水洗し, マスクパターンを形成した。マスクパ ターン形成後, $363 \mathrm{~K}$ に設定したホットプレート上で $180 \mathrm{~s}$ 間ポストベーキングを行い, フォトレジストの硬化を行った。 使用したマスクパターンは, $1 \times 1 \mathrm{~cm}$ の範囲内にマスク寸法 100, 130, $200 \mu \mathrm{m}$ の格子状パターン(開口部面積約 0.48 $\left.\mathrm{cm}^{2}\right)$ を $2 \times 4$ 列で計 8 個配置したものである。マスクパター ン形成後，基板をマスクパターンが 2 個ずつ配置されるよう に 4 分割し, 実験に供した。

\section{2 アノード酸化}

$\mathrm{Al}$ 薄膜のアノード酸化は, 次のように行った。電解液に は, 市販の硫酸(試薬特級)とイオン交換水から調製した $1 \mathrm{vol} \% \mathrm{H}_{2} \mathrm{SO}_{4}$ 水溶液を用い, 浴温度を $293 \mathrm{~K}$ 一定とした。

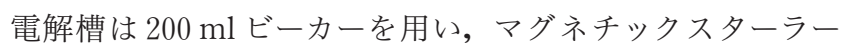
でかく汼した。アノード酸化は直流電源を用い, 陽極に試料 を，陰極に 99.9\% Al 板を設置し，浴電圧を $14,15,16 \mathrm{~V}$ の 3 条件を設定して行った。また電解液は, そのつど新しい ものを使用した。

アノード酸化後, 光学顕微鏡による表面観察と電子線マイ クロアナライザ(EPMA：日本電子製 JXA-8900 RL)によ る元素分析を行い, 酸化膜の形成状況を調査した。また, 酸 化膜の断面構造観察には走査電子顕微鏡(日本電子製 JSM -840 A)を用い, 表面形状の評価には非接触表面粗さ計 (WYKO 社 TOPO-3 D) を用いた。

\section{3. 結果および考察}

\section{1 アノード酸化による酸化膜の形成}

図 1 に浴電圧 $15 \mathrm{~V}$ で $240 \mathrm{~s}$ 処理した試料の表面を光学顕 微鏡で観察した結果を示す。表面観察に際し，表面に残存し ていたフォトレジストは，アセトンで溶解除去した。図 1 に おいて，Aおよび A'は開口部に，B はマスク部にそれぞれ 対応する。アノード酸化することで開口部の $\mathrm{Al}$ 薄膜は, 透 明な酸化膜となっていることが確認できた。一方, マスク部

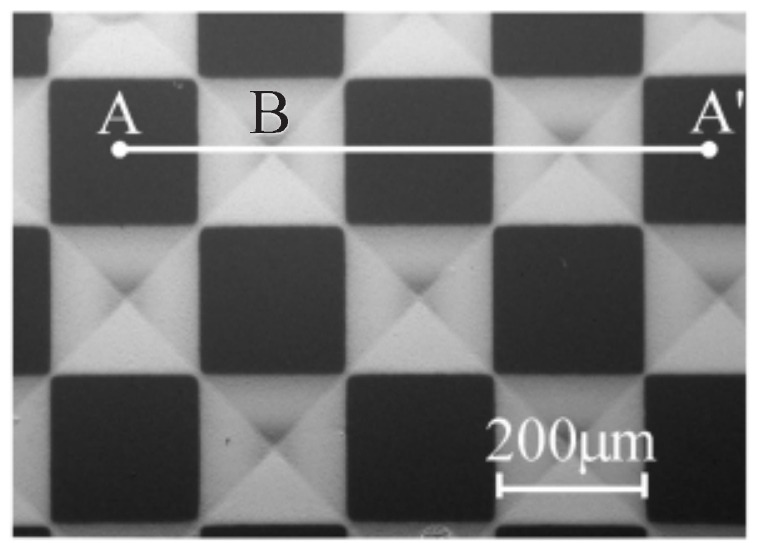

Fig. 1 Optical microscope image of sample surface after anodizing. (Bath Voltage: $15 \mathrm{~V}$, Anodizing time : $240 \mathrm{~s}$, Si substrate)
に相当する部分の $\mathrm{Al}$ 薄膜は, 酸化されずに残存しているが, 陰影のついた状態となっていることが確認できた。

酸化膜の形成状況を確認するために図 1 中 A-A'間を EPMAにより，O(酸素)のライン分析を行った結果を図 2 に示す。また同条件で処理時間を $60,120,180 \mathrm{~s}$ とした試 料の結果も示した。図2より開口部 $\left(\mathrm{A}, \mathrm{A}^{\prime}\right)$ では, 処理時間 の増加とともに O の特性 X 線強度が増加する傾向が認めら れた。また各処理時間ごとの特性 X 線強度は, 開口部端部 からマスク中央部に向かうにつれて緩やかに減少しており, このことは酸化膜の厚さが緩やかに減少していることを示唆 している。

図 3 に各浴電圧で所定時間アノード酸化したときのマスク 下部での酸化膜の形成範囲を計測した結果を示す。このマス ク下部での酸化膜の形成範囲の測定は, 図 2 において O の 特性 X 線強度がバックグラウンド值から開口部での特性 X 線強度の平均值まで変化するのに要する距離を計測すること で求めた。また処理時間 $240 \mathrm{~s}$ のうに, マスク部でバック グラウンドが計測できない場合については，マスク寸法 400 $\mu \mathrm{m}$ のパターンを作製し, 同様に計測を行った。ここで EPMA による表面分析では, 試料表面で電子線の拡がりが

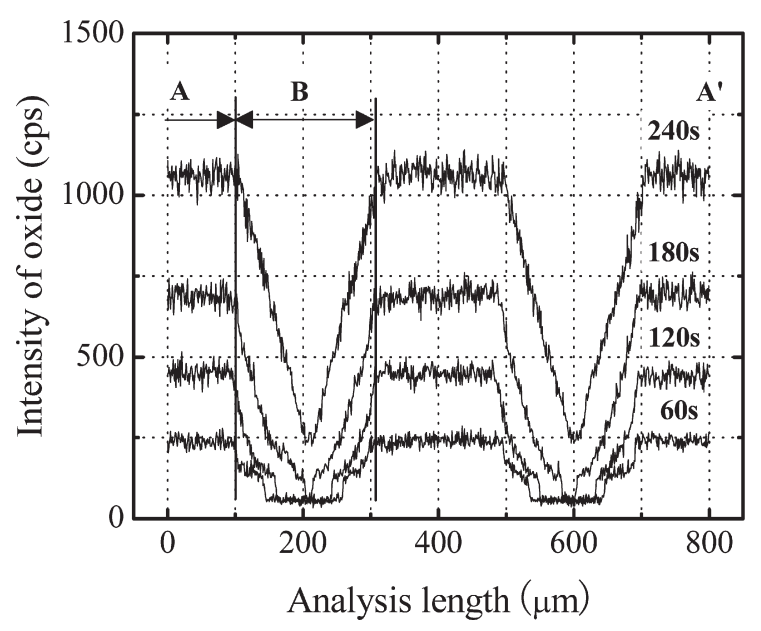

Fig. 2 EPMA line analysis of the cross section for square masked surface after anodizing.

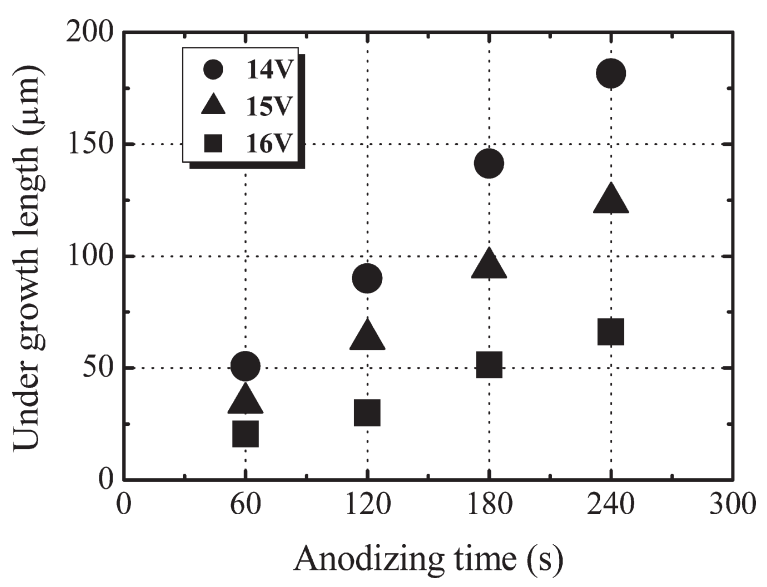

Fig. 3 Relation between under growth length and anodizing time. 
おき，また特性 X線の励起領域は, スポット径として数 $\mu \mathrm{m}$ 程度に拡がるといわれている ${ }^{18)}$ 。このことがマスク下部 の酸化膜形成長さの計測に影響をおよぼすことが考えられる が, 本研究で得られたマスク下部での酸化膜の形成範囲は, いずれの場合でも $10 \mu \mathrm{m}$ 以上であることから，このスポッ ト径の影響は少ないと考えられる。

図 3 より，マスク下部での酸化膜の形成範囲は処理時間の 増加とともに直線的に増加した。このことは，マスク下部に おける酸化膜の形成は，アノード酸化初期から一定の速度で 進行していることを示している。またマスク下部での酸化膜 の形成状況は処理時間と浴電圧に影響され，処理時間を 240 $\mathrm{s}$ とした場合のマスク下部での酸化膜の形成範囲をマスク寸 法 $400 \mu \mathrm{m}$ のパターンで計測したところ, 浴電圧 $16 \mathrm{~V} て ゙$ 約 $65 \mu \mathrm{m}$ ，浴電圧 $15 \mathrm{~V}$ で約 $125 \mu \mathrm{m}$ ，浴電圧 $14 \mathrm{~V}$ では約 180 $\mu \mathrm{m}$ であり, 浴電圧を低下させることでより広い範囲に拡が る傾向を示した。

以上の結果から，マスクパターン形成後にアノード酸化す ることで, 開口部に酸化膜が形成され，またマスク部では， 処理時間 $240 \mathrm{~s}$ で数十〜数百 $\mu \mathrm{m}$ の広範囲にわたり, 酸化膜 の厚さが変化した状態で形成されていることが確認できた。 このようなマスクされた部分に酸化膜が形成される現象につ いての報告例は数少なく ${ }^{13)}$ ，またその形成機構については， ほとんど検証されていない。

そこで，このマスク下部での酸化膜形成機構を調査するた めに, 酸化膜の断面構造を観察した。この結果を図 4 に示す。 断面観察に用いた試料は, $\mathrm{Si}$ 基板上に $\mathrm{Al}$ 薄膜を約 $200 \mathrm{~nm}$ 成膜し，アノード酸化したものを用いた。図４の断面構造観 察結果より, 開口部の酸化膜は, 表面に対しほぼ垂直に配列 した多孔質構造であることが確認できた。一方, マスク下部 の酸化膜は，開口部と同様に表面からほぼ垂直方向に配列し た多孔質構造であり，その下には，アノード酸化されていな い $\mathrm{Al}$ 薄膜を観察することができた。開口部とマスク下部の
酸化膜構造を比較した結果，断面構造に明確な差異は認めら れなかった。この観察結果から, マスク端部から数十〜数百 $\mu \mathrm{m}$ という広い範囲に酸化膜が形成された現象を説明するこ とは困難であり, このことを解明するためには, 次の観点か ら詳細な検討を行う必要があると考えられる。

まず第一に，マスク / $\mathrm{Al}$ 薄膜界面における電解液の挙動 の調査である。これは, マスク下部での酸化膜の形成がマス クと $\mathrm{Al}$ 薄膜界面に浸透した電解液を介して進行した可能性 を検証するうえで必要である。本研究で作製したマスクは, 化学エッチングにも耐えられる密着力があり, 硫酸水溶液中 では化学溶解も起こしにくいことを予備実験で確認している。 しかし，アノード酸化により開口部表面に酸化膜が形成され ることで表面が隆起し，このときにマスク端部を持ち上げる 力が働くことでマスクは $\mathrm{Al}$ 薄膜表面から引きはがされ，こ の隙間に電解液が浸透したことが考えられる。この浸透した 電解液を介してマスク下部でアノード酸化が進行した場合, 酸化膜の断面構造は, 表面から垂直方向の配列した多孔質構 造となるため, 図 4 の断面観察結果とも一致する。このマス ク下部への電解液が浸透した可能性を検証するためには, マ スクの種類や膜厚の影響について調査し, マスク／ $\mathrm{Al}$ 薄膜 界面での電解液の挙動を調査することが必要と考えられる。

第二に Al 薄膜の結晶構造や膜質の影響である。スパッタ リング法や真空蒸着で形成した $\mathrm{Al}$ 薄膜は, 特定の結晶面に 配向する結晶構造になりやすい特徵があり ${ }^{19}$, また薄膜の微 細構造も特徵的な形態をとることが知られている20)。本研究 で成膜した $\mathrm{Al}$ 薄膜も (111) 面に配向している傾向が認めら れ，この構造はマスクパターン形成時に行われる加熱(プレ ベーク，ポストベーク）を経ても，ほとんど変化していない ことをX 線回折により確認している。アノード酸化を行う うえで，アルミニウムの結晶構造は重要な要因であり，特に スパッタリング法で成膜した $\mathrm{Al}$ 薄膜の場合では薄膜のち密

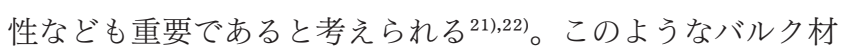

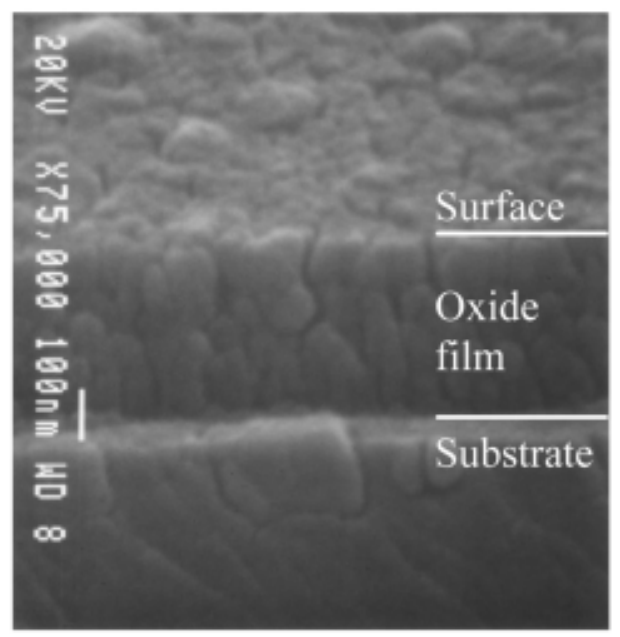

(A)Open surface region

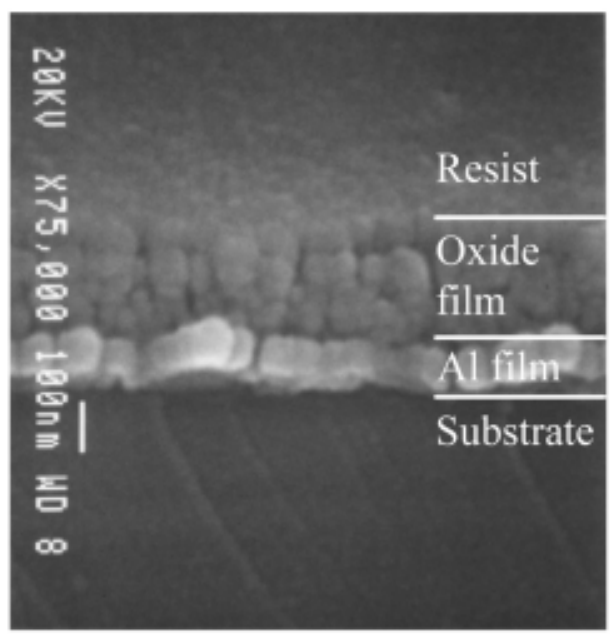

(B)Masked surface region

Fig. 4 SEM image of cross section view of anodic film on Si substrate.

(A) Open surface region

(B) Masked surface region 
料にはない，薄膜特有の材料特性が酸化膜の形成状況におよ ぼす影響についても検討する必要がある。

第三にアノード酸化条件の影響である。たとえば，マスク 下部における酸化膜の形成状況に浴電圧が影響することが図 3 に示されており, このことから浴電圧以外のアノード酸化 条件も酸化膜の形成に影響することが推測できる。このため, 電解液の種類や濃度, 浴温等についても影響を調査する必要 があると考えられる。

これらの影響について検討することで，マスク下部におけ る酸化膜の形成機構を解明することができると考えられる。

\section{3. $2 \mathrm{Ti}$ 層がアノード酸化挙動におよぼす影響}

本研究では, $\mathrm{Al}$ 薄膜の下地層密着性を向上させるために $\mathrm{Ti}$ 膜を約 $10 \mathrm{~nm}$ 形成しているが，この $\mathrm{Ti}$ 層も $\mathrm{Al}$ 薄膜と同 様にアノード酸化されることが考えられ ${ }^{23)}$ ，マスク部でのア ノード酸化挙動に影響を与えている可能性がある。そこで, このことについて検討するために，次の実験を行った。まず， 基板材料にスライドガラスを用い，(1) Ti 層を形成しない場 合，(2) $10 \mathrm{~nm}$ 形成した場合，(3) $20 \mathrm{~nm}$ 形成した場合の 3 種 類の試料に対し，それぞれ $\mathrm{Al}$ 薄膜を $150 \mathrm{~nm}$ 成膜した。そ の後，パターニングを行い，アノード酸化を行った。この時 の浴電圧は $15 \mathrm{~V}$ とし, それぞれの試料に対してアノード酸 化中の電流挙動を測定し, アノード酸化挙動を比較した。こ の結果を図 5 に示す。ここで電流密度は, 初期の開口部面積 $\left(0.96 \mathrm{~cm}^{2}\right)$ を用いて算出した。それぞれの試料の電流密度 一時間曲線は, Ti 層を形成しない試料と $10 \mathrm{~nm}$ 成膜した試 料ではほぼ同様の挙動を示し， $20 \mathrm{~nm}$ 成膜した試料は，これ らとは異なる挙動を示した。この電流挙動の違いは次のよう に考えることができる。まず Ti 層を形成しない試料と 10 $\mathrm{nm}$ 成膜した試料では, 処理時間約 $270 \mathrm{~s}$ で開口部の $\mathrm{Al}$ 薄膜 は厚さ方向にすべてアノード酸化され，そのためにマスクを 形成した部分と電極部分が通電しなくなり, マスク下部の $\mathrm{Al}$ 薄膜は, アノード酸化されずにパターン形状を維持した 状態で $360 \mathrm{~s}$ まで経過したと考えられる。ここで Ti 層が 10 $\mathrm{nm}$ の試料の場合, Ti 層はきわめて薄いために構造的に不 安定になりやすく, $\mathrm{Al} / \mathrm{Ti}$ 界面で合金化したことで, Ti 層 を形成しない場合と類似したアノード酸化挙動を示したと考

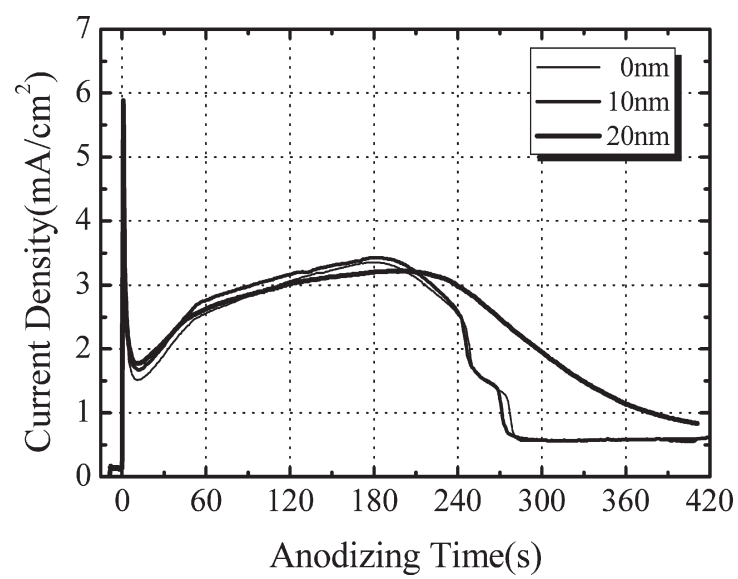

Fig. 5 Current density - time curves during anodaization of $\mathrm{Al}$ films on slide glass.
えられる。また電流值が処理時間約 $240 \mathrm{~s}$ と約 $270 \mathrm{~s}$ の 2 カ 所で急激に低下しているのは, 基板中央部と基板端部で $\mathrm{Al}$ 薄膜の膜厚が異なるために, 先に $\mathrm{Al}$ 薄膜が薄い基板端部の マスクパターン部分のアノード酸化が終了し, ついで中央部 のマスクパターン部分のアノード酸化が終了したことが電流 値の変化として現れたためである。

一方, $\mathrm{Ti}$ 層を $20 \mathrm{~nm}$ 成膜した試料の電流密度-時間曲線 は，処理時間 $270 \mathrm{~s}$ を経過しても急激に減少することなく， 緩やかに減少している。これは, 開口部の $\mathrm{Al}$ 薄膜がすべて アノード酸化された後に下地の Ti 層を介してマスク下部の $\mathrm{A} 1$ 薄膜がアノード酸化されたためである。実際，アノード 酸化後の各試料表面を光学顕微鏡で観察したところ, 処理時 間 $360 \mathrm{~s}$ になると, Ti 層を形成しない試料と $10 \mathrm{~nm}$ 成膜し た試料では，マスク形状が維持されているのに対し，20 nm 成膜した試料では, マスク下部に対応する部分の $\mathrm{Al}$ 部分が 縮小していることが確認できた。

また， $240 \mathrm{~s}$ 処理したときのマスク下部での酸化膜の形成 範囲を光学顕微鏡による観察結果から求めたところ, Ti 膜 厚 $0 \mathrm{~nm}$ で約 $100 \mu \mathrm{m}, 10 \mathrm{~nm}$ で $120 \mu \mathrm{m}, 20 \mathrm{~nm}$ では約 150 $\mu \mathrm{m}$ であった。このことから, 下地層として形成した Ti 層 は, アノード酸化時に $\mathrm{Al}$ 薄膜の通電状態に影響を与え, マ スク下部での酸化膜形成状況に影響することが明らかとなっ た。また基板にスライドガラスを用いた場合のマスク下部で の酸化膜の形成範囲は, Si 基板を用いた場合と異なる結果 となった。この両者の違いは, 酸化膜形成長さの測定方法が 異なるため厳密な比較はできないが, Ti 層の膜厚の影響を 受けた結果と関連して推測することができる。すなわち, 基 板材料がスライドガラスと $\mathrm{Si}$ 基板では抵抗率が異なり, 基 板にスライドガラスを使用した場合, 基板が絶縁材料である ために $\mathrm{Al}$ 薄膜と $\mathrm{Ti}$ 層のみを介してアノード酸化が進行す るのに対し， Si 基板を使用した場合では，薄膜( $\mathrm{Al}$ 薄膜と $\mathrm{Ti}$ 層) と $\mathrm{Si}$ 基板を介して通電しアノード酸化が進行するた め, 基板材料の材質により酸化膜の形成範囲が変化したと考 えられる。

以上の結果から, $\mathrm{Al}$ 薄膜のアノード酸化挙動は, 下地層 ( $\mathrm{Ti}$ 薄膜)の有無やその膜厚, 基板材料の材質に影響される ことが示された。

\section{3 アノード酸化後の表面形状}

マスク形成後にアノード酸化した結果, 開口部とマスク部 分では,アノード酸化膜の厚さが異なる表面状態が得られた。 これにより, 表面に凹凸形状が形成されていることが予想さ れる。そこでアノード酸化処理した試料の表面形状を非接触 表面粗さ計で測定し, 検証を行った。なお,アノード酸化に より形成された酸化膜は透明であり，そのままでは測定が困 難であるため, 表面反射を均一にする目的で，スパッタリン グ装置により表面に Ti 膜を約 $30 \mathrm{~nm}$ 成膜し, 測定に供した。

図 6 に一辺約 $130 \mu \mathrm{m}$ の格子状パターンを浴電圧 $15 \mathrm{~V}$, 処理時間 $270 \mathrm{~s}$ 処理した試料の表面形状測定結果を示す。図 6 (A) 中 C, C’は, 開口部に対応する部分であり,この部分 は平坦であり, 均一に酸化膜が生成していることがわかる。 一方, 中央のマスク部に対応する部分は, マスク端部から中 央部にむけて緩やかな直線的な傾斜を有する四角錐形の窪み 
が形成されている様子が確認できる。図 $6(\mathrm{~A})$ における C -C’断面の形状プロファイルを図 6 (B) に示す。図 6 (B)より, $\mathrm{C} 1-\mathrm{C} 2$ 間距離は約 $127 \mu \mathrm{m}, \mathrm{C} 1-\mathrm{C} 3$ 間の高さは約 $30 \mathrm{~nm}$ で あることから，アスペクト比(高さ/パターン寸法)は, 0.00024 と算出でき，極めて低アスペクト比構造である。

このことから $\mathrm{Al}$ 薄膜表面は, アノード酸化を行うことで 酸化膜が形成され, 隆起していることが確認できた。この現 象について更に詳細に調査するため, 各浴電圧で処理時間を 変化させた試料の隆起高さを測定した。その結果を図 7 に示 す。いずれの浴電圧においても, 処理時間の増加とともに隆 起高さは直線的に増加する傾向を示した。また隆起高さは, 浴電圧に依存し, 浴電圧の増加とともに隆起高さは大きくな

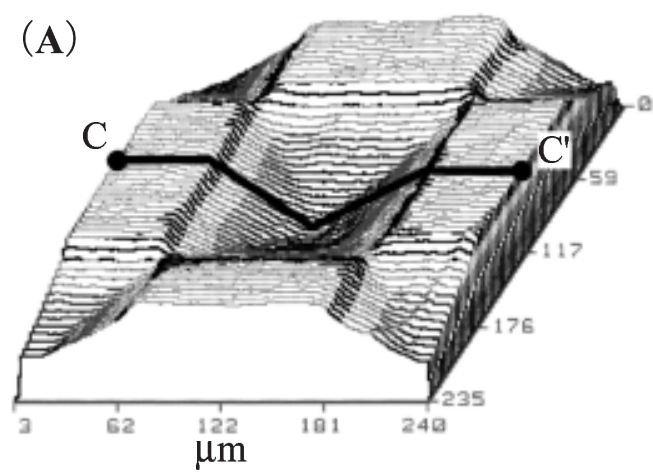

(B)

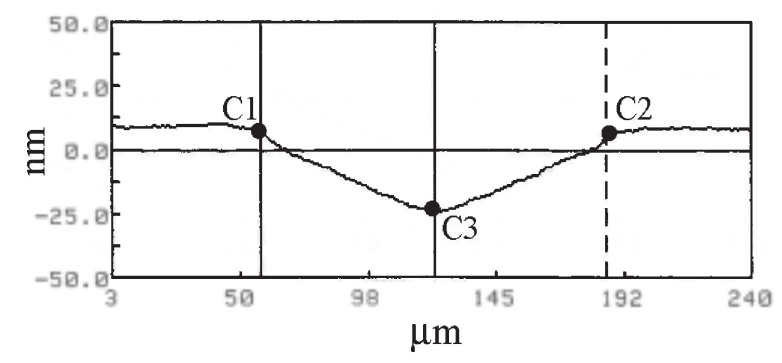

Fig. 6 Surface profile image of anodized Al film.

(A) Three-dimensional image

(B) Sectional image of C-C' line

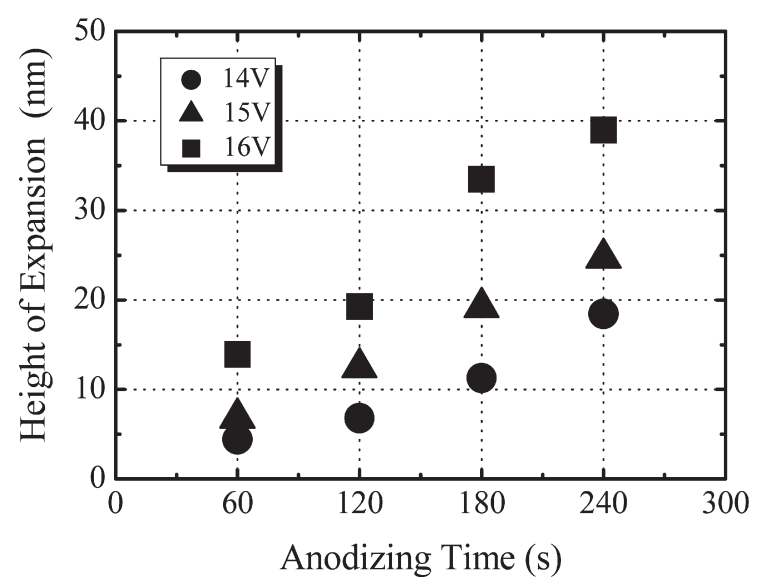

Fig. 7 Relation between height of expansion and anodizing time.
る傾向を示した。これは，浴電圧の増加により単位時間あた りに形成される酸化膜の厚さが増加し, その結果, 隆起高さ が増加したためと考えられる。

以上のことから，浴電圧と処理時間を制御することで，マ スク下部での酸化膜の形成状況と隆起高さが制御でき，ナノ メートルオーダの起伏を有する表面凹凸形状を作製できるこ とが明らかとなった。

\section{4 化学エッチングによる酸化膜の除去}

フォトリソグラフィ後にアノード酸化を行うことで，図 6 に示すように酸化膜の形成による凹凸形状が形成できること が明らかとなった。この部分は, 光学顕微鏡観察結果と EPMA によるライン分析結果から明らかなように, 酸化膜 の厚さの変化によるものである。一方，マスク部の酸化膜の 下には, $\mathrm{Al}$ 薄膜が酸化されずに金属 $\mathrm{Al}$ として残存している。 よって酸化膜を除去し, $\mathrm{Al}$ 薄膜部分を露出させることがで きれば，凹凸形状が反転され，平坦部分に凸形状を得ること ができると考えられる。そこで，このことについて検証する ため, リン酸水溶液による化学エッチングを行い, 酸化膜の 除去を試みた。

まずエッチング時間の最適化を行うために以下の実験を 行った。試料には, 膜厚約 $150 \mathrm{~nm}$ の $\mathrm{Al}$ 薄膜を $1 \mathrm{vol} \%$ $\mathrm{H}_{2} \mathrm{SO}_{4}$ 水溶液中で, 浴電圧 $15 \mathrm{~V}$, 処理時間 $240 \mathrm{~s}$ で酸化膜を 形成したものを用いた。これを $333 \mathrm{~K}$ に加熱した $21 \mathrm{vol} \%$ $\mathrm{H}_{3} \mathrm{PO}_{4}$ 水溶液中に浸漬し, 酸化膜の除去を行った。このと きの浸漬時間は，15，25，35，45 s の 4 段階を設定した。そ れぞれの処理時間浸漬した試料に対し，EPMAにより $\mathrm{O}$, $\mathrm{Al}$ の特性 $\mathrm{X}$ 線強度の測定を行い, 酸化膜の除去効果につい て検討した。

この結果, エッチング時間の増加とともに $\mathrm{O}, \mathrm{Al}$ の特性 $\mathrm{X}$ 線強度は低下し，処理時間 $45 \mathrm{~s}$ で $\mathrm{O}, \mathrm{Al}$ のピークは，ほ とんど認められなくなり, 酸化膜を除去できることが確認で きた。

そこで, エッチング時間を $45 \mathrm{~s}$ に設定し, 酸化膜の除去 を行った。試験に供したマスクとアノード酸化処理は, 図 6 の試料と同一条件である。エッチング前後の EPMA による ライン分析結果を図 8 に示す。エッチング前(図 8 (A)) の O の挙動は, 図 2 と同様に開口部では平坦であり, マスク端部 から中央部に向かうにつれて緩やかに減少している。一方, $\mathrm{A} 1$ の挙動は, マスク端部から中央部に向かうにつれて緩や かに増加する傾向を示した。これに対し，エッチング後では (図 $8(\mathrm{~B})$ ), 開口部では, $\mathrm{O}$ と $\mathrm{Al}$ のピークは, いずれも検 出されず，酸化膜を除去できていることが確認できた。一方， マスク部に対応する部分では，Oのピークは検出されず， $\mathrm{Al}$ のピークのみが検出された。このことから, 化学エッチ ングにより，酸化膜を選択的に除去できることが明らかと なった。このときの $\mathrm{Al}$ の特性 X 線強度は, 緩やかに変化し ていることから, $\mathrm{Al}$ 膜厚も同様に変化していることが予測 できる24)。

そこで図 8 で得られたライン分析結果と表面形状について 検証するために試料の表面形状を非接触表面粗さ計で測定し た結果を図 9 に示す。なお測定面の反射率を整える目的で, 図 6 と同様に Ti 膜を約 $30 \mathrm{~nm}$ 成膜し，測定に供した。 
図 9 (A)において，D,D’はそれぞれ開口部に対応し，中 央の突起部分はマスク部に対応する。試料表面は, 図 9 (B) の結果から明らかなように $\mathrm{Al}$ が残存することで凸形状を呈 しており，マスク形状を反映して四角錐型である。図9(A) における D-D断面の形状プロファイルを図 9 (B) に示す。 図 9 (B)ょり, 断面形状は, 緩やかな傾斜で構成された凸型 形状であることがわかる。このときの D 1-D 2 間距離は 128 $\mu \mathrm{m}, \mathrm{D} 1-\mathrm{D} 3$ 間の高さは $82 \mathrm{~nm}$ であることからアスペクト 比(高さ/パターン寸法) は 0.0064 と算出でき, 極めて低いア スペクト比構造の四角錐が得られた。

以上のことから，化学エッチングにより酸化膜を選択的に 除去することで, 金属 $\mathrm{Al}$ により構成されたナノメートル オーダの微細凸型形状を作製できることが明らかとなった。

\section{5 表面形状創成機構}

以上のフォトリソグラフィとアノード酸化，化学エッチン グを組み合わせた表面加工の模式図を図 10 に示す。

まずスパッタリング法によりシリコンやガラス基板上に $\mathrm{Al}$ 薄膜を形成し $(\mathrm{A})$, フォトリソグラフィによりパターン を形成する $(\mathrm{B})$ 。その後, アノード酸化により, 開口部で酸
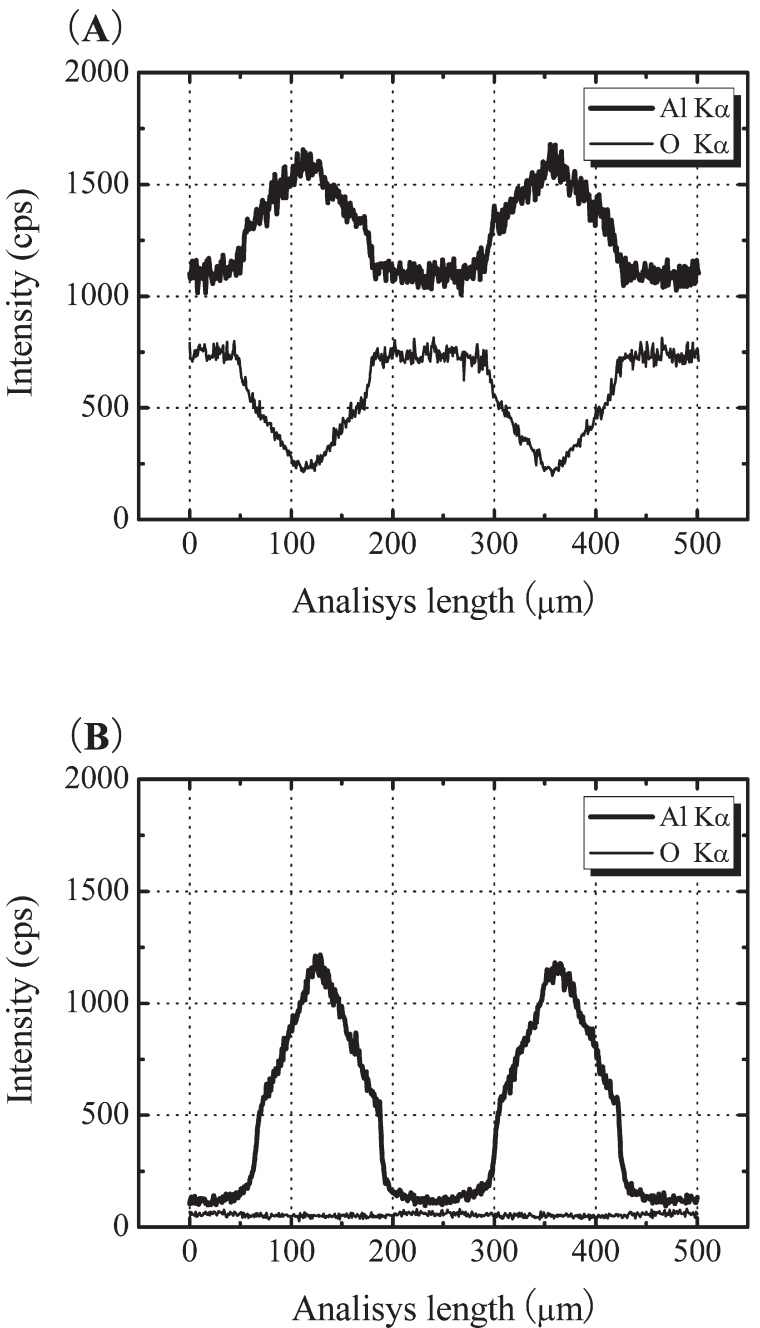

Fig. 8 EPMA line analysis of the cross section for square masked surface.

(A) Before chemical etching
(B) After chemical etching

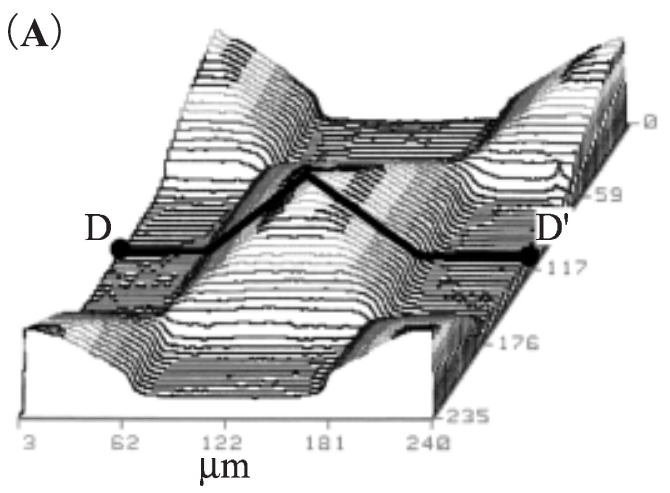

(B)

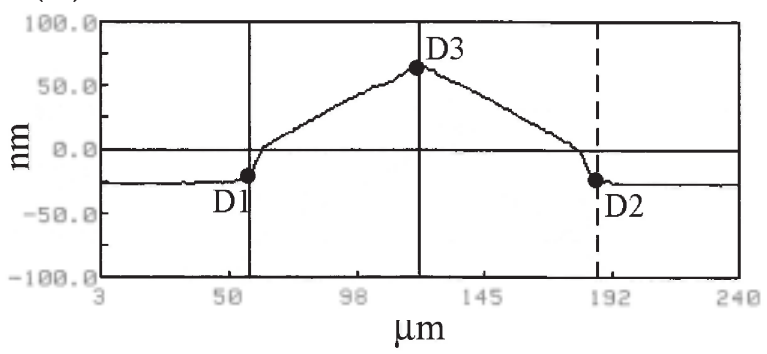

Fig. 9 Surface profile image of anodized $\mathrm{Al}$ film after chemical etching.

(A) Three-dimensional image

(B) Sectional image of D-D' line

(A)

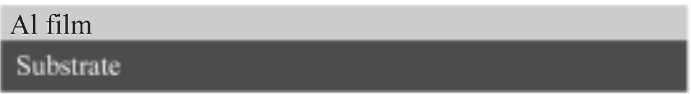

(B)

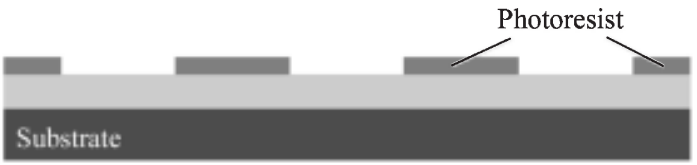

(C)

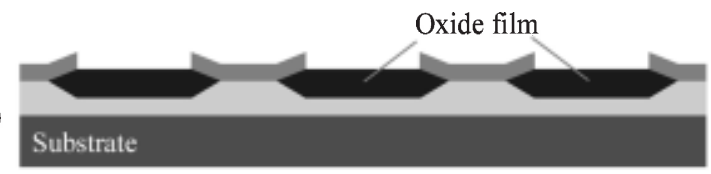

(D)

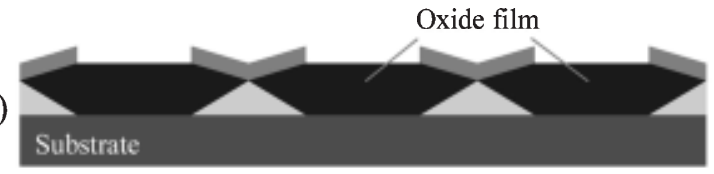

(E)

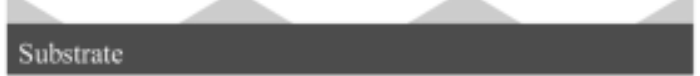

Fig. 10 Schematic model of the surface patterning process using photolithography, anodizing and chemical etching.
(A) Deposited Al film
(B) Make mask patterns
(C, D) Anodization
(E) Chemical etching 
化膜が形成されると同時にマスク下部にも酸化膜が形成され る。このときマスク下部に形成される酸化膜の膜厚は, マス ク端部から中央部に向かうにつれて減少し，表面に緩やかな 傾斜を有する起伏形状が形成される $(\mathrm{C}, \mathrm{D})$ 。この過程での 酸化膜の形成状況が最終的な表面形状を左右し，またエッチ ング後の形状に影響を与えるため, アノード酸化条件の選定 は，重要な因子であると考えられる。たとえば，Al薄膜と 基板間に $\mathrm{Ti}$ 層を形成した場合，この膜厚によってもアノー ド酸化挙動は変化し，また基板材料の影響も受ける。このた め表面形状を制御するためには, より詳細な処理条件の検証 が必要である。さらに化学エッチングにより酸化膜を選択的

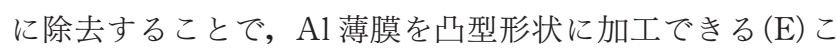
とが明らかとなった。

\section{4. 結言}

スパッタリング法で成膜した $\mathrm{Al}$ 薄膜に対し，フォトリソ グラフィとアノード酸化を利用した表面加工について検討を 行った結果，次のことが明らかになった。

1) マスク形成後にアノード酸化を行うことで, 開口部とマ スク下部に酸化膜が形成された。このマスク下部での酸化膜 の形成状況は, 処理時間と浴電圧の影響を受けた。

2) $\mathrm{Al}$ 薄膜のアノード酸化挙動は，下地層として形成した Ti 膜の有無，膜厚の影響を受け，また基板材料により異な る傾向を示した。

3 ）アノード酸化により酸化膜が形成されたことで開口部の 表面は隆起した。一方，マスク下部の酸化膜はマスク端部か ら中央部で形成厚さが異なるため, 表面に窪み形状が形成さ れた。

4 ) 酸化膜は, リン酸水溶液を用いた化学エッチングにより 選択的に除去できた。その結果, 金属 $\mathrm{A} 1$ で構成された, 低 アスペクト比の凸型形状を作製できた。

これらの結果からフォトリソグラフィとアノード酸化, 化 学エッチングの組合せにより, ナノメートルオーダの起伏を 有する低アスペクト比の凹凸形状を作製できることが明らか となり, このことから, 新しい表面加工方法としての可能性 を見出すことができた。

(Received July 30, 2007 ; Accepted March 12, 2008)

\section{文献}

1) S. Miyake and J. Kim ; JSPE, 65, 1788 (1999) (in Japanese).

2) T. Hosono and H. Tokura ; JSPE, 71, 729 (2005) (in Japanese).
3 ) N. Morita and N. Kawasegi ; J. Surface Finish. Soc. Jpn., 56, 852 (2005) (in Japanese).

$4)$ N. Saito, T. Ishizaki, S. Lee and O. Takai ; J. Surface Finish. Soc. Jpn., 56, 930 (2005) (in Japanese).

5 ) M. Shimomura and H. Yabu ; J. Surface Finish. Soc. Jpn., 55, 770 (2004) (in Japanese).

6 ) M. Kobayashi ; J. Surface Finish. Soc. Jpn., 56, 769 (2006) (in Japanese).

7 ) H. Tanaka and K. Inoue ; Hyomen Gijutsu, 51, 780 (2000) (in Japanese).

$8)$ S. Yamashita, H. Tanaka, Y. Abe, T. Yamauchi, O. Takenaka and K. Inoue; Hyomen Gijutsu, 52, 783 (2001) (in Japanese).

9 ）佐藤敏一; 電解加工と化学加工, p. 255 (朝倉書店, 1970).

10) A. Oide, H. Asoh and S. Ono; Electrochemistry, 74, 379 (2006) (in Japanese).

11) K. Nishio and H. Masuda ; J. Surface Finish. Soc. Jpn., 55, 897 (2004) (in Japanese).

12) M. Saito, H. Muto, H. Asho and S. Ono ; J. Surface Finish. Soc. Jpn., 55, 937 (2004) (in Japanese).

13) M. J. Barela, D. A. Brevnov, T. M. Bauer, G. P. Lopez and P. B. Atanassov ; Electrochem. Solod-State Lett., 8, C 30 (2005).

14) S. Langa, S. Frey, J. Carstensen, H. Foll, I. M. Tiginyanu, M. Hermann and G. Bottger ; Electrochem. Solod-State Lett., 8, C 4 (2005).

15) T. Mineta ; J. Surface Finish. Soc. Jpn., 54, 145 (2003) (in Japanese).

16) E. Makino, T. Shibata and D. Allen ; Hyomen Gijutsu, 49, 887 (1998) (in Japanese).

17) T. Mineta ; J. Surface Finish. Soc. Jpn., 54, 693 (2003) (in Japanese).

18）堀内繁雄, 弘津禎彦, 朝倉健太郎; 電子顕微鏡 Q\&A, p. 120 (アグネ承風社, 1996).

19) M. Kamijo and N. Katsumata; Yamanashi Prefectural Industrial Technology Center Report, 14, 31 (2000) (in Japanese).

20）日本学術振興会薄膜第 131 委員会 ; 薄膜ハンドブック, p. 179 (オーム社, 1983).

21) K. Wada, S. Z. Chu and S. Inoue ; J. JILM, 54, 579 (2004) (in Japanese).

22) K. Wada, S. Z. Chu and S. Inoue; Ceramics Japan, 40, 470 (2005) (in Japanese).

23) S. Z. Chu, S. Inoue, K. Wada, S. Hishita and K. Kurashima ; J. Electrochem. Soc., 152, B 116 (2005).

24) N. Katsumata, M. Ishida and O. Saito ; Yamanashi Prefectural Industrial Technology Center Report, 20, 33 (2006) (in Japanese). 